\title{
EVALUASI VIABILITAS BENIH, KETAHANAN DAN PEMULIHAN TANAMAN EMPAT PEDIGRI INBRED JAGUNG YANG DISIMPAN LEBIH DARI DUA BELAS BULAN
}

\author{
Gusti Ayu Ningrum, Saiful Hikam \& Paul B. Timotiwu \\ Jurusan Agroteknologi, Fakultas Pertanian Universitas Lampung \\ Jl. Prof. Soemantri Brodjonegoro, No.1 Bandar Lampung 35145 \\ E-mail:goestee_kirei@yahoo.com
}

\begin{abstract}
ABSTRAK
Salah satu upaya meningkatkan produktivitas jagung adalah mengembangkan varietas unggul yang berdaya hasil tinggi dan adaptif pada kondisi lingkungan tertentu. Perakitan varietas unggul dimulai dengan membentuk galur atau lini inbred sebagai calon tetua. Inbred adalah individu dengan derajat kehomozigotan yang tinggi yang dicapai melalui self (menyerbuk sendiri) secara berulang. Benih self yang telah disimpan 12-24 bulan mengalami penurunan viabilitas. Penurunan viabilitas dapat dicegah dengan teknik penyimpanan benih yang baik. Untuk memperoleh benih dengan mutu awal yang tinggi, lingkungan pertanaman termasuk kesuburan tanah diusahakan pada kondisi optimal. Salah satu caranya yaitu dengan pemupukan. Kelangkaan pupuk yang terjadi menyebabkan penundaan pupuk pada awal pertumbuhan tanaman. Dengan demikian, inbred perlu diseleksi agar dapat bertahan terhadap ketiadaan pupuk dasar pada fase bibit selama 25-30 hari setelah tanam (hst). Vigor bibit yang kuat akan mampu bertahan walaupun dalam keadaan tercekam. Pemulihan diperlukan untuk melihat vigor bibit dapat meningkat dan menghasilkan tanaman yang normal. Pemberian pupuk NPK diharapkan dapat merangsang pertumbuhan vegetatif tanaman sehingga membantu pemulihan tanaman. Penelitian ini bertujuan untuk (1) mengevaluasi viabilitas benih jagung yang telah disimpan lebih dari 12 bulan, (2) mengetahui ketahanan hidup tanaman tanpa tambahan pupuk sampai umur 28 hst, dan (3) mengevaluasi pemulihan tanaman setelah penambahan pupuk. Perlakuan disusun dalam Rancangan Kelompok Teracak Sempurna (RKTS) dengan tiga ulangan. Bahan tanaman yang digunakan adalah empat benih inbred yaitu UL4.01 (Srikandi), UL3.03 (BiSi 3), UL2.03 (Cargill 3), dan UL1.04 (Pioneer 4). Kehomogenan data dianalisis menggunakan uji Bartlett dan Levene. Jika hasil analisis ragam yang diperoleh nyata, maka dilakukan pemeringkatan nilai tengah dengan uji Beda Nyata Jujur (BNJ) pada á 5\%. Tingkat Pertumbuhan dianalisis dengan trend line melalui Microsoft Excel. Hasil penelitian menunjukkan bahwa (1) Empat pedigri inbred jagung memiliki persentase viabilitas benih >86\% yaitu UL4.01 95\%, UL3.03 100\%, UL2.03 94\%, dan UL1.04 100\%; (2) Keempat pedigri inbred jagung mampu bertahan hidup tanpa adanya tambahan pupuk sampai umur 28 hst, (3) Setelah diberi pupuk keempat pedigri inbred jagung tidak menunjukkan terjadinya pemulihan.
\end{abstract}

Kata Kunci: jagung, benih inbred, viabilitas benih, pedigri, pemulihan tanaman.

\section{PENDAHULUAN}

Salah satu upaya untuk meningkatkan produktivitas jagung adalah mengembangkan varietas unggul yang berdaya hasil tinggi dan adaptif pada kondisi lingkungan tertentu (Kartasapoetra, 2003). Perakitan varietas unggul dimulai dengan membentuk galur atau lini inbred sebagai calon tetua. Inbred dapat dibentuk menggunakan bahan dasar varietas bersari bebas atau hibrida, dan inbred lain. Pembentukan inbred dari varietas bersari bebas atau hibrida pada dasarnya melalui seleksi tanaman (Takdir et al., 2007). Inbred adalah individu dengan derajat kehomozigotan yang tinggi yang dicapai melalui self berulang (Hikam, 2003).

Efek dari self yang terus menerus akan memunculkan sifat jelek karena meningkatnya kehomozigotan. Pada Tanaman jagung ditunjukan oleh depresi inbriding antara lain penurunan viabilitas dan vigor misalnya tinggi tanaman menjadi kerdil dan produksi menjadi rendah (Copeland dan McDonald, 2001).

Benih self (inbred) yang telah disimpan $12-24$ bulan mengalami penurunan viabilitas. Benih self yang berhasil berkecambah (viabel) mampu tumbuh vegetatif dan berproduksi dengan baik. Penurunan viabilitas dapat dicegah dengan teknik penyimpanan benih yang baik (Hikam, 2008). Menurut Justice dan Bass (1994) menurunnya vigor dan kematian benih dapat dilihat dari dua aspek: (1) hilangnya viabilitas atau matinya sekelompok benih; (2) kematian suatu individu benih. Proses kematian benih terjadi secara perlahan-lahan, sehingga sulit untuk menentukan waktu kehidupan benih itu berakhir. Pada suatu kelompok benih, proses kehidupan individu benih tidak berlangsung dalam laju 
yang sama. Benih yang disimpan pada berbagai keadaan, proses kehidupannya berakhir pada waktu yang tidak sama. Enzim-enzim tertentu masih berfungsi untuk sementara meski benihnya telah mati.

Pupuk merupakan salah satu faktor penting bagi tanaman namun harganya mahal dan langka dipasar. Hal ini menyebabkan para pemulia kesulitan memberikan pupuk pertama untuk tanaman. Dengan demikian, inbred perlu diseleksi agar dapat bertahan terhadap ketiadaan pupuk dasar pada fase bibit selama 25-30 hari setelah tanam (hst).

Selama fase bibit tersebut vigor tanaman akan terseleksi. Vigor bibit yang kuat akan mampu bertahan walaupun dalam keadaan tercekam. Agar vigor bibit dapat meningkat dan menghasilkan tanaman yang normal diperlukan pemulihan. Salah satu cara pemulihan mungkin dapat dilakukan dengan pemberiaan pupuk NPK dengan harapan pupuk ini dapat merangsang pertumbuhan vegetatif tanaman.

Penelitian bertujuan untuk: (1) Mengevaluasi viabilitas benih jagung yang telah disimpan lebih dari 12 bulan, (2) Mengetahui ketahanan hidup tanaman tanpa tambahan pupuk sampai umur 28 hst, (3) Mengevaluasi pemulihan tanaman setelah penambahan pupuk.

\section{BAHAN DAN METODE}

Penelitian ini dilakukan di Laboratorium Benih, Universitas Lampung, Bandar Lampung sejak bulan Juli sampai dengan bulan September 2010.

Bahan-bahan yang digunakan adalah empat pedigri inbred jagung adalah yaitu UL4.01 (pedigri Srikandi), UL3.03 (pedigri BiSi 3), UL2.03 (pedigri Cargill 3), dan UL1.04 (pedigri Pioneer 4), air suling dan pupuk NPK majemuk yaitu Hyponex. Alat-alat yang digunakan dalam penelitian ini adalah: Growth Chamber tipeIPB 7A/B, electric conductivity meter, rumah plastik, kertas merang, gelas plastik, stayrofoam, solder, neraca elektrik, tissue, hand sprayer, kertas label, lembaran plastik, karet gelang, nampan, oven listrik, gunting/cutter, gelas ukur, kotak kardus A4, spatula, penggaris, dan alat tulis.
Penelitian menggunakan 4 pedigri jagung yaitu Srikandi (UL4.01), BiSi 3 (UL3.03), Cargill 3 (UL2.03), dan Pioneer 4 (UL1.04) dengan tiga ulangan yang disusun dalam Rancangan Kelompok Teracak Sempurna(RKTS). Kehomogenan data dianalisis menggunakan uji Bartlett dan Levene. Data untuk semua peubah yaitu panjang turus, panjang akar, jumlah akar cabang, jumlah daun, bobot kering turus, dan bobot kering akar + sisa biji dianalisis menggunakan Analysis of Variance (Anova) melalui Minitab 14. Jika hasil analisis ragam yang diperoleh nyata, maka dilakukan pemeringkatan nilai tengah dengan uji Beda Nyata Jujur (BNJ) pada $\alpha_{0,05}$. Tingkat Pertumbuhan dianalisis dengan trend line melalui Microsoft Excel.

\section{HASIL DAN PEMBAHASAN}

Hasil penelitian menunjukkan bahwa rata-rata benih memiliki viabilitas yang tinggi. Hal tersebut dapat dilihat pada Tabel 1. Nilai konduktivitas yang besar pada sekelompok benih, diimbangi dengan daya kecambah yang rendah. Benih Cargill 3 mempunyai nilai konduktivitas perendaman paling besar dari benih-benih yang lain, tetapi daya kecambahnya tidak jauh berbeda dari benih yang lainnya. Tabel 1 juga menunjukkan antara benih tahun 2010 dan 2008 daya kecambahnya sama-sama tinggi. Hal tersebut karena kondisi benih masih bagus.

Viabilitas benih yang telah disimpan lebih dari 12 bulan ternyata tetap menunjukkan viabilitas yang baik karena persentase kecambah yang dihasilkan di atas 90 $\%$, yang memenuhi standar viabilitas benih bermutu. Hal tersebut menandakan bahwa penyimpanan pada kondisi tidak mempengaruhi penurunan viabilitas benih pada saat disimpan, diduga proses pengolahan benih yang mempengaruhi penurunan viabilitas.

Hasil penelitian menunjukkan terdapat benih mati dan benih leachate (Tabel 1). Benih mati karena nirviabel yaitu benih yang tidak mampu berimbibisi. Benih mati karena leachate, benih tersebut berimbibisi namun mengalami kebocoran dinding sel sehingga tidak mampu berkecambah. Menurut Berliando (2008) untuk

Tabel 1. Rerata bobot 100 butir benih jagung, daya hantar listrik (DHL) perendaman, benih mati, dan daya kecambah

\begin{tabular}{cccccccc}
\hline $\begin{array}{c}\text { Kode } \\
\text { inbred }\end{array}$ & Pedigri & $\begin{array}{c}\text { Tahun } \\
\text { panen }\end{array}$ & $\begin{array}{c}\text { Bobot 100 butir } \\
(\mathrm{g})\end{array}$ & $\begin{array}{c}\text { DHL awal } \\
(\mu \mathrm{S} / \mathrm{cm})\end{array}$ & $\begin{array}{c}\text { DHL akhir } \\
(\mu \mathrm{S} / \mathrm{cm})\end{array}$ & $\begin{array}{c}\text { Benih mati } \\
(\%)\end{array}$ & $\begin{array}{c}\text { Daya kecambah } \\
(\%)\end{array}$ \\
\hline UL4.01 & Srikandi & 2010 & 20,39 & 322 & 747 & 5 & 95 \\
UL2.03 & BiSi 3 & 2008 & 21,40 & 325 & 640 & 0 & 100 \\
UL3.03 & Cargill 3 & 2008 & 26,69 & 323 & 1618 & 6 & 94 \\
UL1.04 & Pioneer 4 & 2008 & 31,51 & 325 & 883 & 0 & 100 \\
\hline
\end{tabular}


benih leachate dicirikan benih tidak berkecambah dan mengalami pembengkakan atau bentuknya tidak sama dengan kondisi awal.

Pengukuran nilai konduktivitas digunakan untuk mengukur kemampuan akar melakukan pertukaran ion, mengeluarkan ion yang terkandung di dalam akar tanaman, dan menyerap unsur hara yang terlarut di dalam media tumbuh yang digunakan untuk pertumbuhan tanaman seperti yang terlihat pada Tabel 2.

Tabel 2 menunjukkan nilai konduktivitas yang besar. Hal tersebut menunjukkan akar tanaman mengeluarkan eksudat akar yang kemudian bertukar dengan hara yang terkandung dalam media tumbuh. Diharapkan unsur hara yang diserap tanaman dimanfaatkan untuk meningkatkan panjang turus, panjang akar, jumlah daun, jumlah akar cabang, bobot kering turus, dan bobot kering akar + sisa biji.
Meningkatnya nilai konduktivitas menandakan adanya kebocoran benih. Semakin besar kebocoran benih maka harapan benih untuk tumbuh akan semakin kecil. Hal ini disebabkan benih akan membocorkan bahan-bahan yang dikandungnya. Bahan-bahan yang dikeluarkan benih pada peristiwa tersebut antara lain $\mathrm{K}, \mathrm{Cl}$, gula, dan asam amino yang merupakan bahan baku pembentukan energi yang akan digunakan dalam proses perkecambahan. Oleh karena itu, benih yang mengalami leachete akan sulit sekali untuk tumbuh.

Gambar 1-6 menunjukkan grafik kecenderungan pertumbuhan pedigri jagung untuk setiap peubah. Pada grafik menjelaskan kecenderungan tanaman mengalami pertumbuhan meskipun mengalami cekaman unsur hara diawal pertumbuhan, akibat tidak dipupuk selama 28 hari. Hal tersebut dapat dilihat dari peubah yang diamati menunjukkan pertambahan panjang, jumlah, dan bobot

Tabel 2. Nilai konduktivitas $(\mu \mathrm{S} / \mathrm{cm})$ empat pedigri jagung yang diberi tambahan pupuk selama 14 hari

\begin{tabular}{ccccc}
\hline Hari & Pedigri & $\begin{array}{c}\text { dhl larutan pupuk } \\
\text { pada h28 }(\mu \mathrm{S} / \mathrm{cm})\end{array}$ & $\begin{array}{c}\text { dhl larutan pupuk pada } \\
\text { h35 dan h42 }(\mu \mathrm{S} / \mathrm{cm})\end{array}$ & $\begin{array}{c}\text { Nilai Konduktivitas } \\
(\mu \mathrm{S} / \mathrm{cm})\end{array}$ \\
\hline $28-35$ & UL4.01 & 15390,00 & 27866,67 & 12476,67 \\
$28-35$ & UL3.03 & 15390,00 & 29566,67 & 14176,67 \\
$28-35$ & UL2.03 & 15390,00 & 30000,00 & 14610,00 \\
$28-35$ & UL1.04 & 15390,00 & 31433,33 & 16043,33 \\
$35-42$ & UL4.01 & 15390,00 & 30900,00 & 15510,00 \\
$35-42$ & UL3.03 & 15390,00 & 40966,67 & 25576,67 \\
$35-42$ & UL2.03 & 15390,00 & 42500,00 & 27110,00 \\
$35-42$ & UL1.04 & 15390,00 & 33266,67 & 17876,67 \\
\hline
\end{tabular}

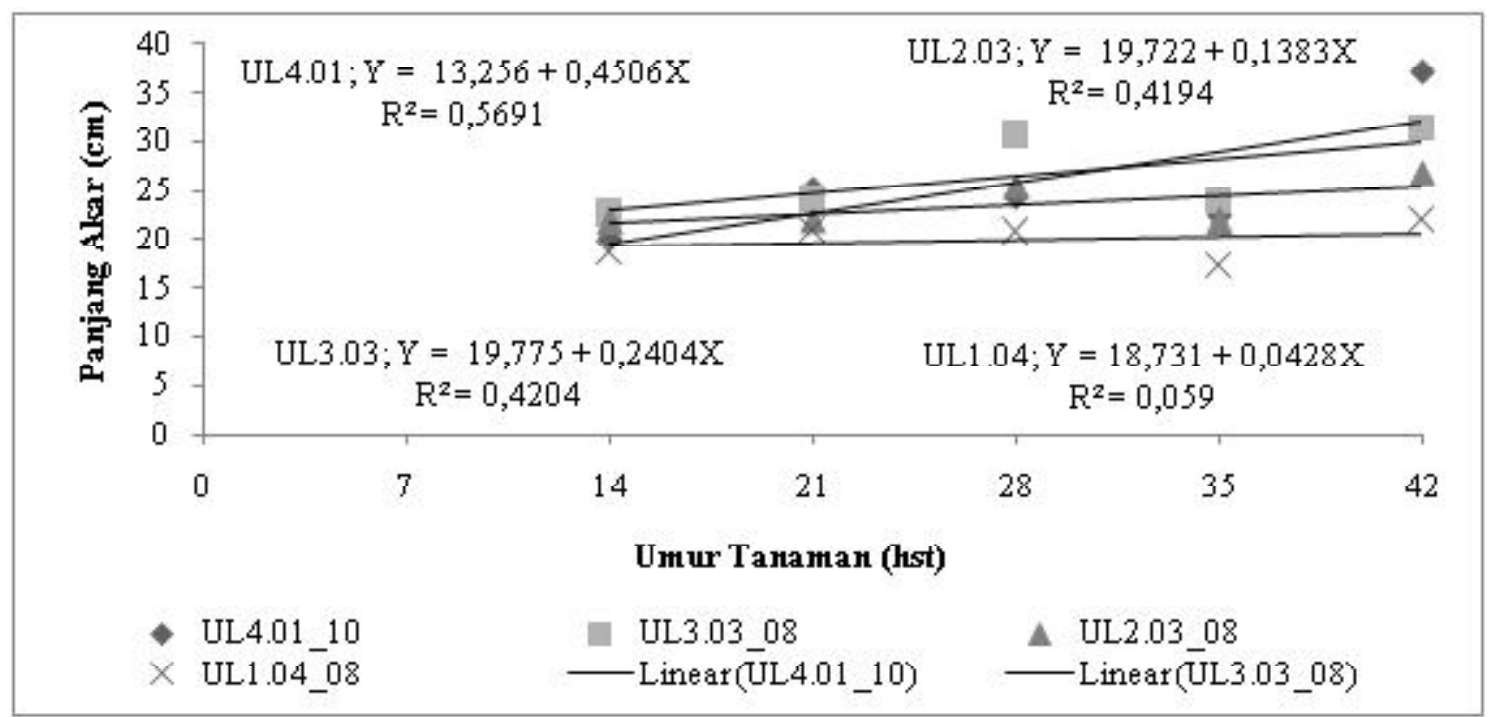

Gambar 1. Kecenderungan pertumbuhan untuk panjang turus empat pedigri jagung. 


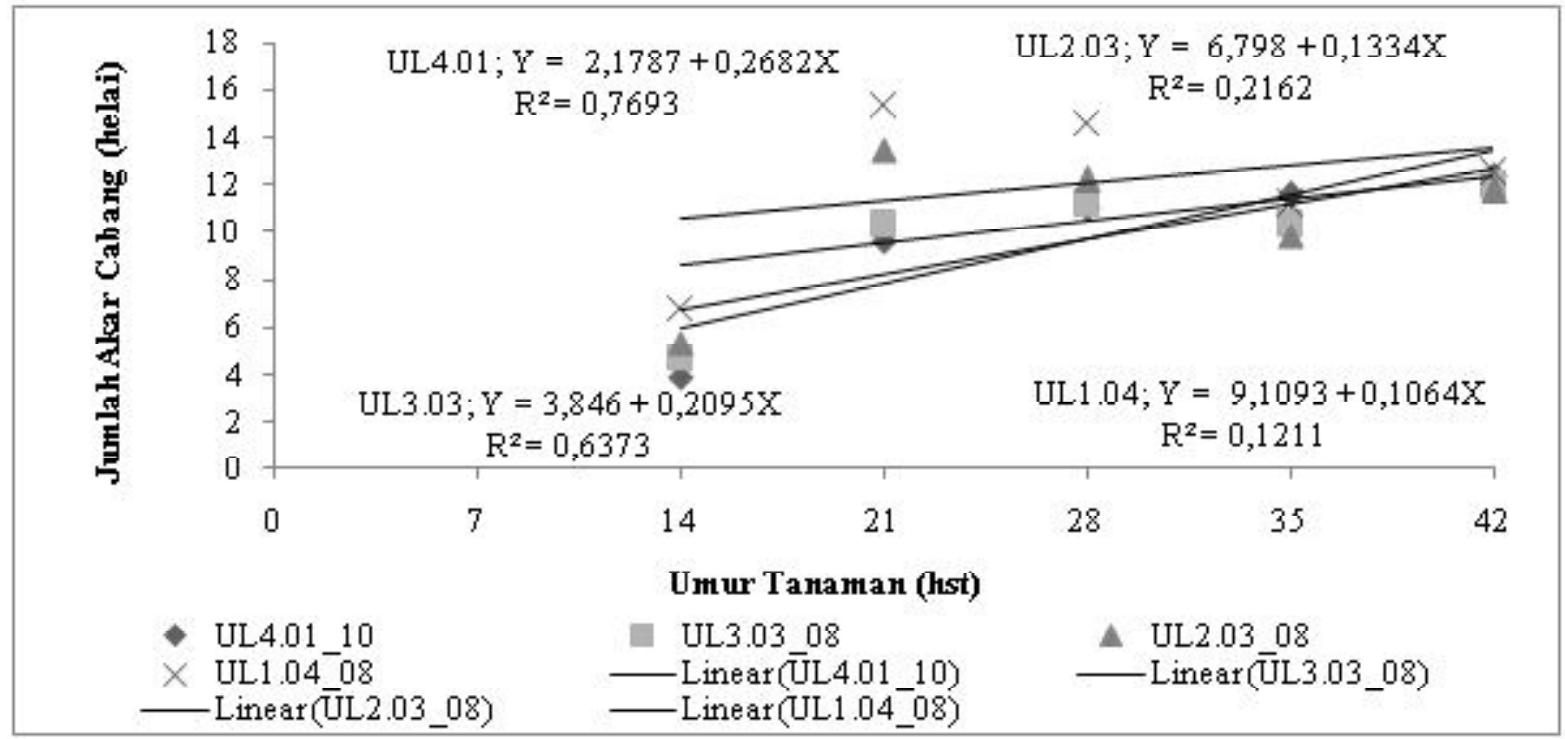

Gambar 2. Kecenderungan pertumbuhan untuk panjang akar empat pedigri jagung.

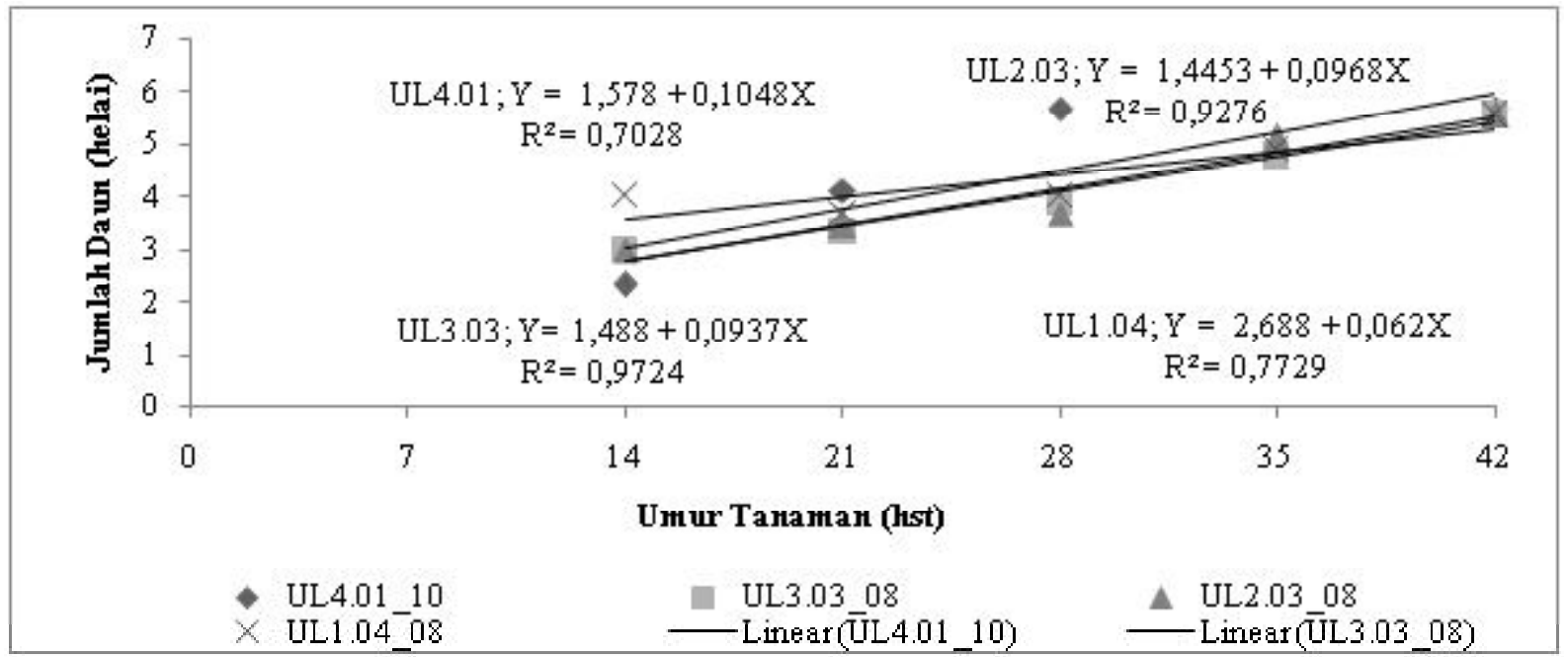

Gambar 3. Kecenderungan pertumbuhan untuk jumlah akar cabang empat pedigri jagung.

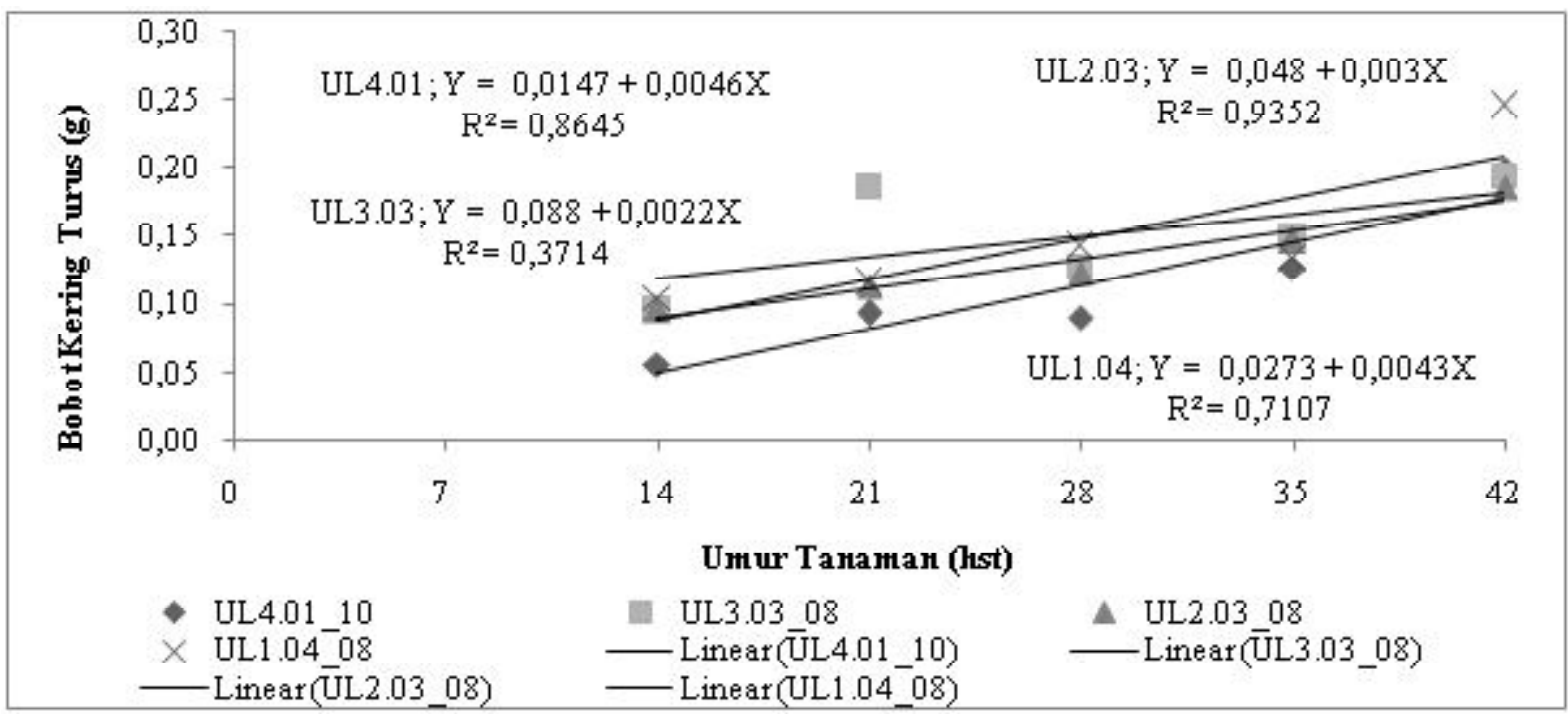

Gambar 4. Kecenderungan pertumbuhan untuk jumlah daun empat pedigri jagung. 


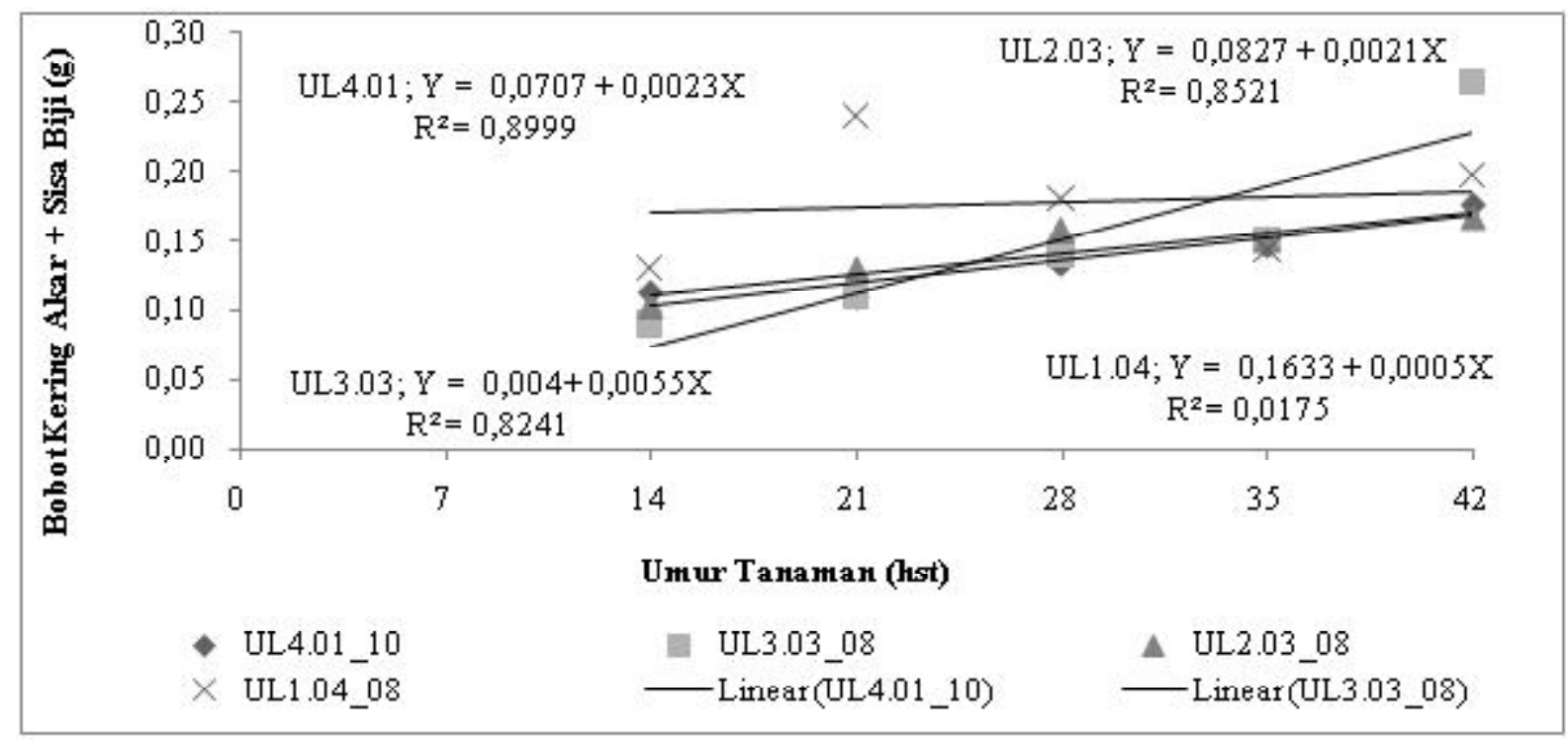

Gambar 5. Kecenderungan pertumbuhan untuk bobot kering turus empat pedigri jagung.

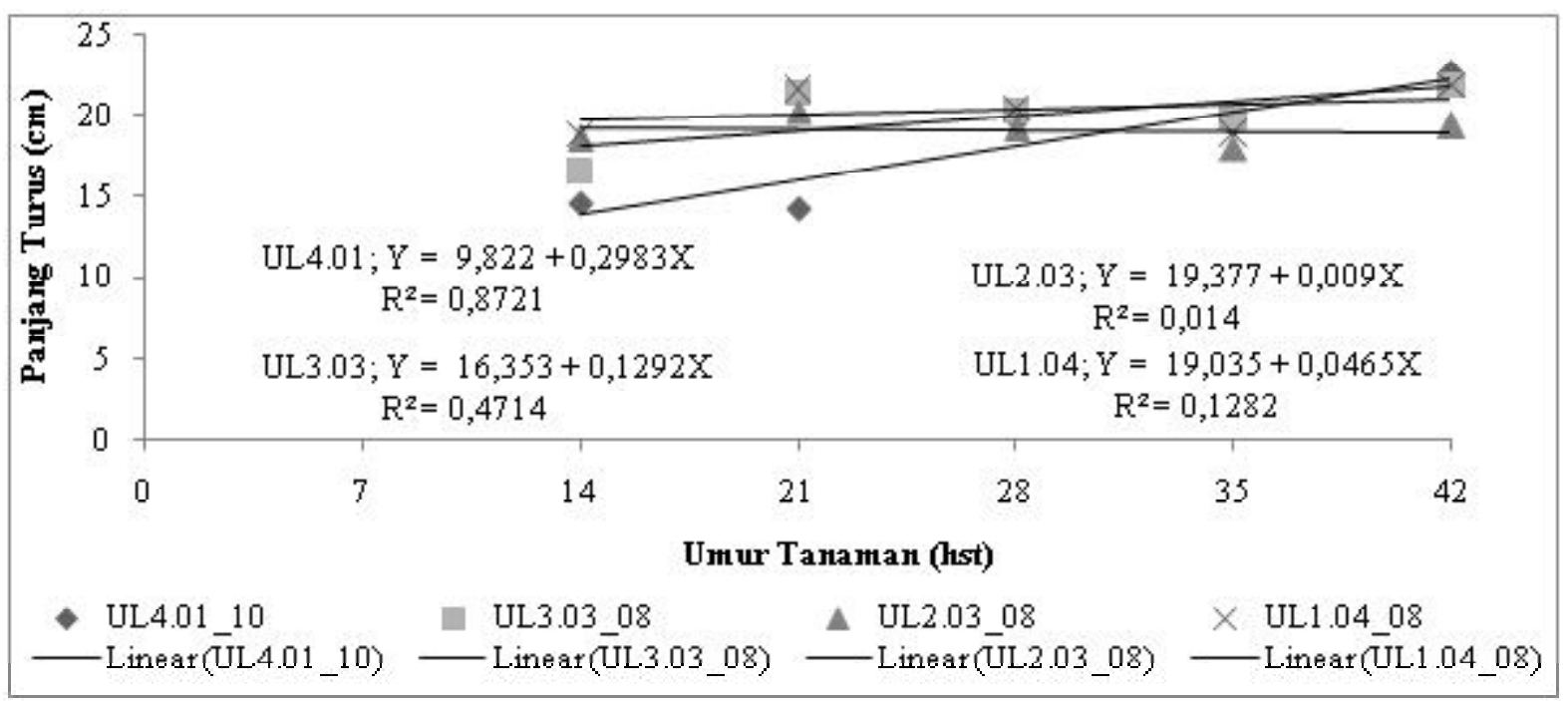

Gambar 6. Kecenderungan pertumbuhan untuk bobot kering akar + sisa biji empat pedigri jagung.

pada beberapa pedigri. Sedangkan pedigri yang tidak menunjukkan peningkatan pertumbuhan, pedigri tersebut tidak tahan terhadap cekaman unsur hara.

Gambar 1-6 keempat pedigri untuk peubah panjang turus, panjang akar, jumlah akar, jumlah daun, bobot kering turus dan bobot kering akar + sisa biji tidak menunjukkan adanya pemulihan. Hal tersebut dapat dilihat dari pertumbuhan tanaman tidak sama dengan tanaman normal. Pemulihan adalah kemampuan tanaman untuk tumbuh normal kembali setelah mengalami cekaman unsur hara.

Dari grafik juga menunjukkan bahawa keempat pedigri jagung tidak menujukkan adanya perbedaan pertumbuhan untuk semua peubah yang diamati. Hal ini ditunjukkan dengan penambahan untuk panjang turus, panjang akar, jumlah akar cabang, jumlah daun, bobot kering turus, dan bobot kering akar + sisa biji sama laju pertumbuhan sama.

\section{KESIMPULAN}

Dari hasil penelitian dapat disimpulkan bahwa empat pedigri inbred jagung memiliki persentase viabilitas benih > $86 \%$ yaitu UL4.0195\%, UL3.03 100 $\%$, UL1.04 $94 \%$, dan UL1.04 $100 \%$. Keempat pedigri inbred jagung mampu bertahan hidup tanpa adanya tambahan pupuk sampai umur 28 hst. Setelah diberi 
pupuk pada umur 35-42 hst pada keempat pedigri tidak menunjukkan terjadinya pemulihan pada setiap peubah yang diamati.

\section{DAFTAR PUSTAKA}

Arda, B. 2009. Imbibisi Biji. http:// arenlovesu.blogspot.com/2009/08/imbibisi-bijilaporan-oleh-bram-arda.html

Badan standardisasi nasional (BSN). 2006. Ketetapan SNI untuk Air Minum Indonesia. http://bbia.go.id/ sertifikasi/SNI\%2001-3553-2006\%5B1\% 5D\%20AMDK.pdf

Balai Penelitian Tanaman Serealia. 2010. Deskripsi Varietas. http:// balit sereal. litbang. deptan. go. id/ind/images/stories/deskripsi06.pdf.

Berliando, C. 2008. Keragaman Leachate, Viabilitas Benih, dan Vigor Bibit Jagung Manis yang Dipupuk dengan Semen Portland. Skripsi. Universitas Lampung. Lampung. $44 \mathrm{hlm}$.

Copeland, L.O. and M.B. McDonald. 2001. Principles of Seed Science and Technology. Kluwer Academic Publishers. London. 467 pp.

Fatih, A. 2011. Pengaruh Kadar Air Terhadap Pertumbuhan Jagung. http://blog.ub.ac.id/ abufatih/2011/12/05/pengaruh-kadar-airterhadap-pertumbuhan-jagung/

Hikam, S. 2003. Teknik Penghibridan Tanaman. Fakultas Pertanian Universitas Lampung. Bandar Lampung. Belum diterbitkan. $38 \mathrm{hlm}$.

Hikam, S. 2008. Pemuliaan Tanaman Lanjutan. Fakultas Pertanian Universitas Lampung. Bandar Lampung. Belum diterbitkan $36 \mathrm{hlm}$.

Hikam, S. 2010. Teknik Perencanaan dan Analisis Pemuliaan Tanaman. Fakultas Pertanian Universitas Lampung. Bandar Lampung. Naskah Lepas $11 \mathrm{hlm}$.

Justice, O.L., dan L.N. Bass. 1994. Prinsip dan Praktek Penyimpanan Benih Diterjemahkan oleh Rennie Roesli dari Principles dan Practice of Seed Storage. PT Raja Grafindo Persada. Jakarta. $446 \mathrm{hlm}$.
Kartasapoetra, A.G. 2003. Teknologi Benih, Pengolahan Benih dan Tuntutan Praktikum. PT. Rineka Cipta: Jakarta. 188 hlm.

Litbang Pangan. 2011. Deskripsi Varietas Cargill dan BiSi. Pangan.litbang. deptan.go.id d/ hwww.puslittan.bogor.net.

Mangoendidjojo, W. 2003. Dasar-Dasar Pemuliaan Tanaman. Kanisius. Yogyakarta. $182 \mathrm{hlm}$.

Pramono, E. 2007. Bahan Ajar Kemunduran Benih. Fakultas Pertanian Universitas Lampung. Bandar Lampung.

Purwanti, S. 2004. Kajian Suhu Ruang Simpan terhadap Kualitas Benih Kedelai Hitam dan Kedelai Kuning. Jurnal Ilmu Pertanian. Vol 11. No.1. hal 22-31.

Sadjad, S. 1976. Kertas Merang Untuk Uji Viabilitas Benih di Indonesia. Institut Pertanian Bogor. Bogor. $181 \mathrm{hlm}$.

Sadjad, S. 1994. Kuantifikasi Metabolisme Benih. PT Widia Sarana Indonesia. Jakarta. $145 \mathrm{hlm}$.

Saenong, S., M. Azrai, dan R. Arief. 2010. Pengelolaan Benih Jagung. Http://balitsereal.litbang. deptan.go. id/ind/bjagung/sebelas.pdf.

Subekti, N.A., Syafruddin, R. Efendi, S. Sunarti. 2010. Morfologi Tanaman dan Fase Pertumbuhan Jagung. Http://balit-sereal.litbang.deptan.go..id/ ind/bjagung/empat.pdf.

Sutopo, L. 1993. Teknologi Benih. Rajawali Pers. Jakarta. $221 \mathrm{hlm}$

Takdir, A., S. Sunarti, dan M.J. Mejaya. 2007. Pembentukan Varietas Jagung Hibrida dalam Jagung: Teknik Produksi dan Pengembangan. Balai Penelitian tanaman Serealia. Sulawesi Selatan.

Wikipedia. 2009. Jagung. http://agrica.wordpress.com/ 2009/01/03/difusi-osmosis-dan-imbibisi/Jagung 